\title{
Optical Properties of Erbium and Erbium/Ytterbium Doped Polymethylmethacrylate
}

\author{
V. Prajzler, V. Jeřábek, O. Lyutakov, I. Hüttel, J. Špirková, V. Machovič, J. Oswald, \\ D. Chvostová, J. Zavadil
}

In this paper we report on the fabrication and properties of $\mathrm{Er}^{3+}$ and $\mathrm{Er}^{3+} / \mathrm{Yb}^{3+}$ doped Polymethylmethacrylate (PMMA) layers. The reported layers were fabricated by spin coating on silicon or on quartz substrates. Infrared spectroscopy was used for an investigation of $O-H$ stretching vibration. Measurement were made of the transmission spectra in the wavelength ranges from 350 to $700 \mathrm{~nm}^{\mathrm{mor}}$ the Er ${ }^{3+}$ doped samples and from 900 to $1040 \mathrm{~nm}$ for the $\mathrm{Yb}^{3+}$ doped samples. The refractive indices were investigated in the spectral range from 300 to $1100 \mathrm{~nm}$ using optical ellipsometry and the photoluminescence spectra were measured in the infrared region.

Keywords: polymer, polymethylmethacrylate, Erbium, Ytterbium, optical properties.

\section{Introduction}

In recent years, Rare Earth (RE) ions containing photonics materials have attracted much attention for their potential applications for full color displays, optical sources and laser systems such as optical amplifiers [1-6]. A list of the RE elements with some of their basic properties is shown in Table 1.

Most research has focused on RE ions which can emit in the visible region. Steckl et al. reported in [7] about the properties of $\mathrm{GaN}$ layers doped with $\mathrm{Eu}^{3+}, \mathrm{Er}^{3+}$, and $\mathrm{Tm}^{3+}$ ions. They obtained (for the first time) photoemission from higher excited RE states in GaN covering the entire visible spectrum: light emission in the green (from Er at 537/558 nm), red (Pr at $650 \mathrm{~nm}$ and $\mathrm{Eu}$ at $621 \mathrm{~nm}$ ), and blue (Tm at $477 \mathrm{~nm}$ ) spectral regions. A second major field of study deals with RE ions which can emit in the infrared region. For these purposes, the $\mathrm{RE}$ ions are most often studied for telecommunications systems. For telecommunication systems operating at $1300 \mathrm{~nm}$ investigations are made of $\mathrm{RE}$ ions such as $\mathrm{Nd}^{3+}$, $\mathrm{Pr}^{3+}$ and $\mathrm{Dy}^{3+}[8-11]$. For telecommunications applications at $1530 \mathrm{~nm}$, investigations are made of $\mathrm{Er}^{3+}$ and $\mathrm{Tm}^{3+}$ ions [12-14]. In the last decade there have also been investigations of sensitizers to produce more efficient RE doped sources. The most often used sensitizer is $\mathrm{Yb}^{3+}$ for $\mathrm{Er}^{3+}$-doped optical amplifiers $[15,16]$. In addition to $\mathrm{Yb}^{3+}$ other $\mathrm{RE}$ ions are nowadays examined as sensitizers, such as $\mathrm{Ho}^{3+}$ for $\mathrm{Tm}^{3+}$ $[17,18]$ or $\mathrm{Ho}^{3+}$ for $\mathrm{Yb}^{3+}[19]$ doped photonics materials, etc. [20].

Optical materials such as semiconductors, glass and optical crystals doped with RE ions are conventional materials for accomplishing lasing action. Recently there has been considerable interest in the development of new photonics materials such as polymers [21, 22], which have better properties and a lower price.

In this paper, we present the fabrication and properties of $\mathrm{Er}$ and $\mathrm{Er} / \mathrm{Yb}$ doped polymer layers. As a polymer material we chose Polymethylmethacrylate (PMMA), due to its low optical absorption, simple synthesis and low cost. These characteristics make it a suitable host material for RE ions [23, 24]. $\mathrm{Er}^{3+}$ ions were chosen due to fact that $\mathrm{Er}^{3+}$ ions now play a key role in long-distance optical communication systems. $\mathrm{Yb}^{3+} \mathrm{co}-$
Table 1: The rare earth elements and some of their properties

\begin{tabular}{|c|c|c|c|}
\hline $\begin{array}{l}\text { Atomic } \\
\text { number }\end{array}$ & Element & $\begin{array}{c}\text { Electron } \\
\text { configuration } \\
\mathrm{RE}^{3+}\end{array}$ & $\begin{array}{c}\text { Ground } \\
\text { term } \\
\mathrm{RE}^{3+}\end{array}$ \\
\hline 58 & Cerium - Ce & $4 f^{1} 5 s^{2} 5 p^{6}$ & ${ }^{2} \mathrm{~F}_{5 / 2}$ \\
\hline 59 & Praseodymium - Pr & $4 \mathrm{f}^{2} 5 \mathrm{~s}^{2} 5 \mathrm{p}^{6}$ & ${ }^{3} \mathrm{H}_{4}$ \\
\hline 60 & Neodymium - Nd & $4 f^{3} 5 s^{2} 5 p^{6}$ & ${ }^{4} \mathrm{I}_{9 / 2}$ \\
\hline 61 & Promethium - Pm & $4 f^{4} 5 s^{2} 5 p^{6}$ & ${ }^{5} \mathrm{I}_{4}$ \\
\hline 62 & Samarium - Sm & $4 f^{5} 5 s^{2} 5 p^{6}$ & ${ }^{6} \mathrm{H}_{5 / 2}$ \\
\hline 63 & Europium - Eu & $4 f^{6} 5 s^{2} 5 p^{6}$ & ${ }^{7} \mathrm{~F}_{0}$ \\
\hline 64 & Gadolinium - Gd & $4 f^{7} 5 s^{2} 5 p^{6}$ & ${ }^{8} \mathrm{~S}_{7 / 2}$ \\
\hline 65 & Terbium - Tb & $4 f^{8} 5 s^{2} 5 p^{6}$ & ${ }^{7} \mathrm{~F}_{6}$ \\
\hline 66 & Dysprosium - Dy & $4 \mathrm{f}^{9} 5 \mathrm{~s}^{2} 5 \mathrm{p}^{6}$ & ${ }^{6} \mathrm{H}_{15 / 2}$ \\
\hline 67 & Holmium - Ho & $4 f^{10} 5 s^{2} 5 p^{6}$ & ${ }^{5} \mathrm{I}_{8}$ \\
\hline 68 & Erbium - Er & $4 f^{11} 5 s^{2} 5 p^{6}$ & ${ }^{4} \mathrm{I}_{5 / 2}$ \\
\hline 69 & Thulium - Tm & $4 f^{12} 5 s^{2} 5 p^{6}$ & ${ }^{3} \mathrm{H}_{6}$ \\
\hline 70 & Ytterbium - Yb & $4 \mathrm{f}^{13} 5 \mathrm{~s}^{2} 5 \mathrm{p}^{6}$ & ${ }^{2} \mathrm{~F}_{7 / 2}$ \\
\hline
\end{tabular}

-doping was applied because it was previously shown that the addition of ytterbium ions increased the intensity of the luminescence at $1530 \mathrm{~nm}$ [16].

\section{Experiment}

Small pieces of PMMA (Goodfellow) were left to dissolve in chloroform for a few days before being used in the fabrication of PMMA layers. The PMMA layers were fabricated by spin coating on silicon substrates or the polymer was poured into a bottomless mold placed on a quartz substrate and left to dry. For RE doping anhydrous $\mathrm{ErCl}_{3}$ and $\mathrm{YbCl}_{3}$ or $\mathrm{ErF}_{3}$ and $\mathrm{YbF}_{3}$ or erbium(III) tris(2,2,6,6-tetramethyl-3,5-heptanedio- 
<smiles>[3H]CC(C)(C)C(=O)OC</smiles>

Fig. 1: Molecular structure of PMMA

nate) (Sigma-Aldrich) and ytterbium(III) tris(2,2,6,6-tetramethyl-3,5-heptanedionate) (Goodfellow) were dissolved in $\mathrm{C}_{5} \mathrm{H}_{9} \mathrm{NO}$ or $\mathrm{C}_{2} \mathrm{H}_{6} \mathrm{OS}$ (Sigma-Aldrich).

The layers were fabricated in such a way that the content of erbium in the solutions varied from 1.0 at. \% to 20.0 at. \%, and were then added to the polymer. The samples containing 1.0 at. $\%$ of erbium were co-doped with ytterbium $\left(\mathrm{Er}^{3+} / \mathrm{Yb}^{3+}\right.$ samples) in amounts varying from 1.0 at. \% to 20.0 at. \%. The molecular structure of PMMA is shown in Fig. 1. The molecular structure of $\mathrm{ErCl}_{3}$ shown in Fig. 2a, the structure of $\mathrm{ErF}_{3}$ in Fig. 2b, and that of erbium(III) tris(2,2,6,6- tetramethyl-3,5-heptanedionate) and ytterbium(III) tris(2,2,6,6-tetramethyl-3,5-heptanedionate) are shown in Fig. 2c.

\section{Results and discussion}

The samples were characterized by infrared spectroscopy (FT-IR) using a Bruker IFS 66/v FTIR spectrometer equipped with a broadband MCT detector, to which 128 interferograms were added with a resolution of $4 \mathrm{~cm}^{-1}$ (Happ-Genzel apodization). Fig. 3 displays the FT-IR spectra of PMMA layers doped with $\mathrm{Er}^{3+}$ ions $\left(\mathrm{ErCl}_{3}\right)$ in the wavelength range from 4000 to $2600 \mathrm{~cm}^{-1}$.

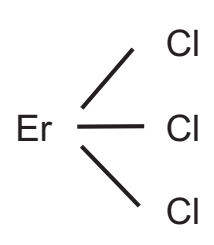

a)

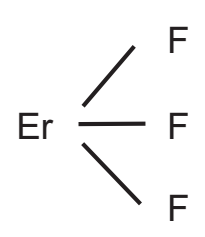

b)

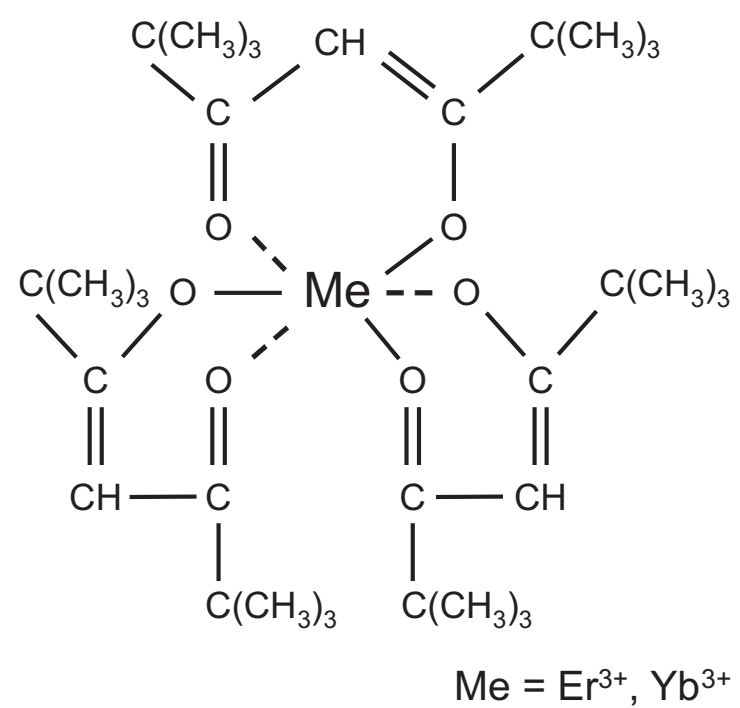

c)

Fig. 2: Molecular structure of a) $\mathrm{ErCl}_{3}$, b) $\mathrm{ErF}_{3}$ and c) erbium(III) and ytterbium(III) ions

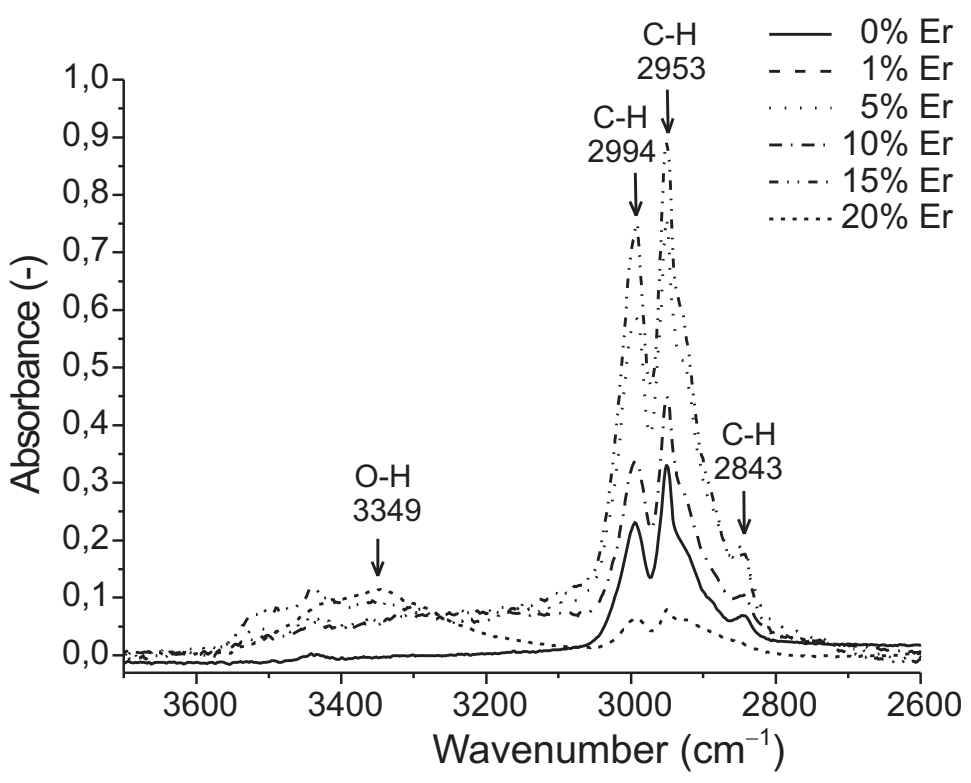

Fig. 3: Infrared spectra of PMMA samples doped with $\mathrm{Er}^{3+}$ using $\mathrm{ErCl}_{3}$ 


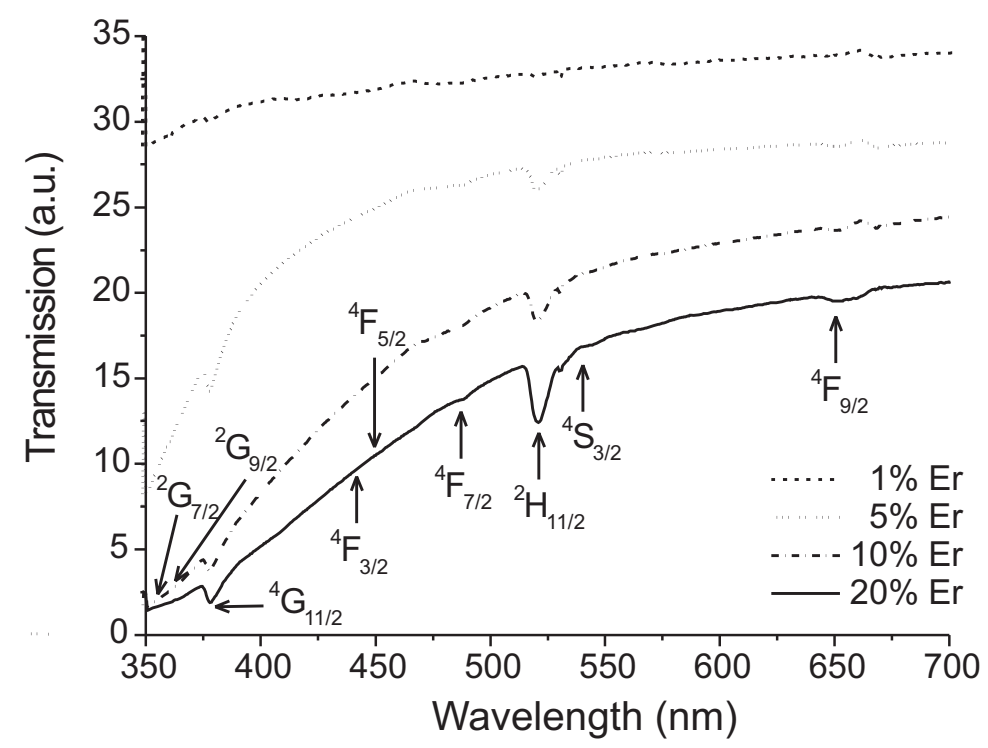

Fig. 4: Transmission spectra of the $\mathrm{Er}^{3}+$ doped PMMA using erbium(III)

The three strong broad bands occurring at $2994 \mathrm{~cm}^{-1}$, $2953 \mathrm{~cm}^{-1}, 2843 \mathrm{~cm}^{-1}$ correspond to the aliphatic C-H bands. These bands are assigned to the stretching vibrations of $\mathrm{CH}_{3}$ and $\mathrm{CH} 2$, and indicate a high content of hydrogen-rich $\mathrm{CH}_{x}$. The absorption band at $3349 \mathrm{~cm}^{-1}$ corresponds to the $\mathrm{O}-\mathrm{H}$ stretching vibrations of the PMMA layers. Fig. 3 also shows that increasing the $\mathrm{Er}^{3+}$ content also increased the intensity of the $\mathrm{O}-\mathrm{H}$ vibrations. This can be explained by the fact that $\mathrm{ErCl}_{3}$, as very hygroscopic substance, not only dopes the polymer samples also but bring a certain amount of water. It is a well-known fact that the presence of $\mathrm{O}-\mathrm{H}$ groups in a matrix containing rare earth ions unfortunately causes problems by hindering emission in the infrared region.

The transmission measurements were performed using a UV-VIS-NIR Spectrometer (UV-3600 Shimadzu) in the spectral range from 350 to $700 \mathrm{~nm}$. The transmission spectra of the $\mathrm{Er}^{3+}$ doped polymer (erbium(III)) in the spectral range from $350 \mathrm{~nm}$ to $700 \mathrm{~nm}$ are shown in Fig. 4. In the samples containing 10.0 at. $\%$ of $\mathrm{Er}^{3+}$, two bands appeared that were attributed to the following transitions: ${ }^{4} \mathrm{G}_{11 / 2}(377 \mathrm{~nm})$ and ${ }^{2} \mathrm{H}_{11 / 2}(519 \mathrm{~nm})$. In the samples containing 20.0 at. \% of $\mathrm{Er}^{3+}$ one more band appeared at ${ }^{4} \mathrm{~F}_{9 / 2}(650 \mathrm{~nm})$. We did not observe bands ${ }^{2} \mathrm{G}_{7 / 2}(355 \mathrm{~nm}),{ }^{2} \mathrm{G}_{9 / 2}(363 \mathrm{~nm}),{ }^{2} \mathrm{H}_{9 / 2}(405 \mathrm{~nm})$, ${ }^{4} \mathrm{~F}_{3 / 2}(441 \mathrm{~nm}),{ }^{4} \mathrm{~F}_{5 / 2}(448 \mathrm{~nm}),{ }^{4} \mathrm{~F}_{7 / 2}(485 \mathrm{~nm})$ and ${ }^{4} \mathrm{~S}_{3 / 2}$ $(539 \mathrm{~nm})$. The same results were obtained for samples doped with $\mathrm{ErCl}_{3}$ and $\mathrm{ErF}_{3}$ solution.

The transmission spectra of the $\mathrm{Er}^{3+}(1.0$ at. \%) doped polymers co-doped with $\mathrm{Yb}^{3+}$ ions using erbium(III) and ytterbium(III) (from 1.0 at. \% to 20.0 at. \%) in the spectral range from $900 \mathrm{~nm}$ to $1040 \mathrm{~nm}$ are shown in Fig. 5. The sample containing 20.0 at. $\%$ of $\mathrm{Yb}^{3+}$ ions has a typical $\mathrm{Yb}^{3+}{ }^{2} \mathrm{~F}_{5 / 2}$ transition with maxima at $977 \mathrm{~nm}$. The samples

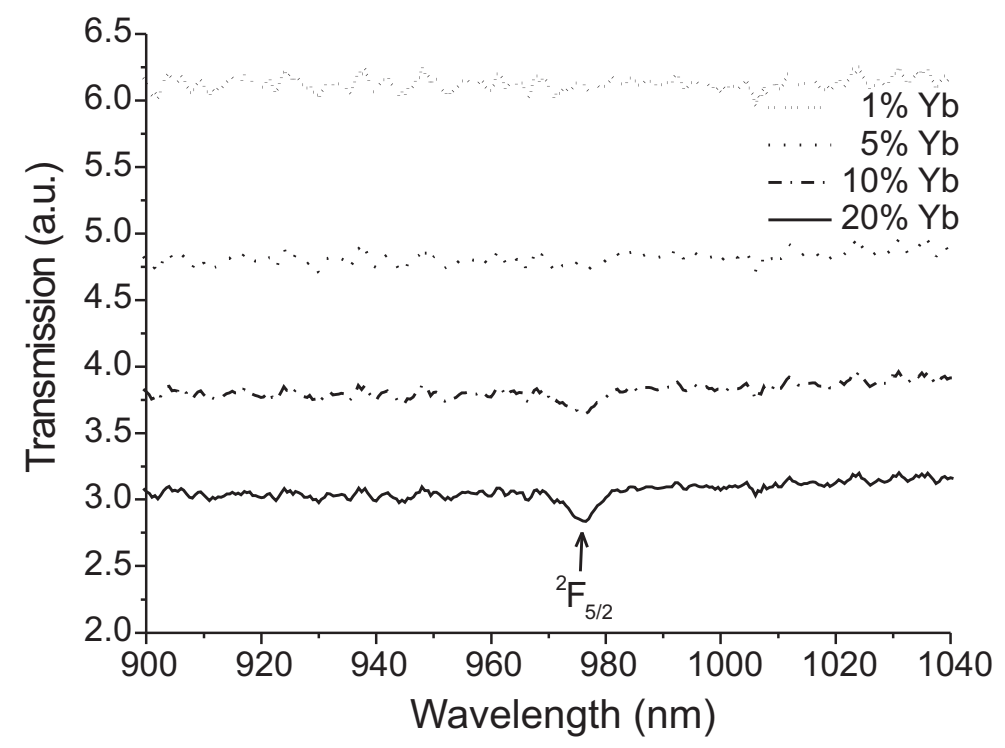

Fig. 5: Transmission spectra of $\mathrm{Er}^{3+}\left(1.0\right.$ at.\%) doped PMMA co-doped with $\mathrm{Yb}^{3+}$ using erbium(III) and ytterbium(III) ions 


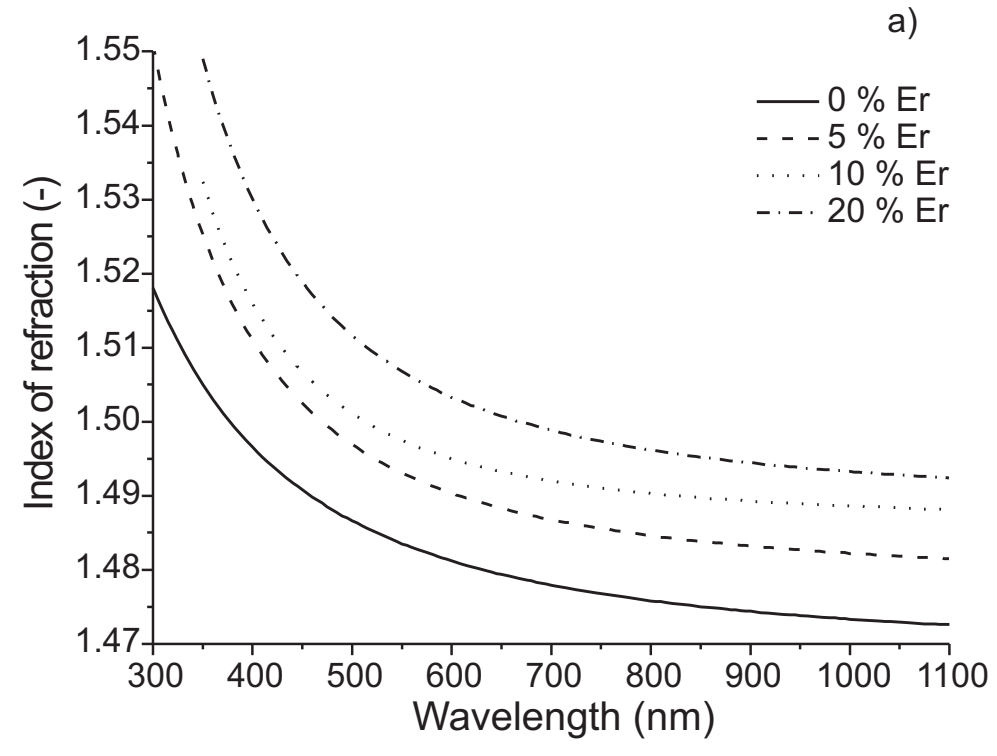

b)

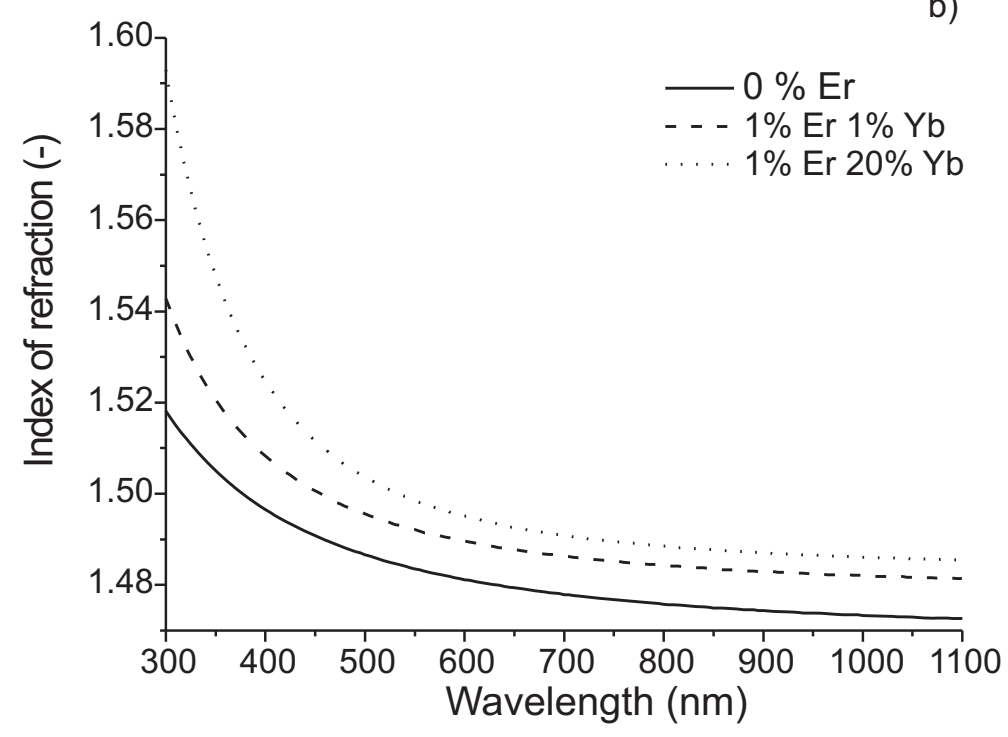

Fig. 6: Wavelength dependence of the refractive indices a) of the $\mathrm{Er}^{3+}$ and b) $\mathrm{Er}^{3+}+\mathrm{Yb}^{3+}$ doped PMMA layers using erbium(III) and ytterbium(III)

with a lower concentration have a weaker ${ }^{2} \mathrm{~F}_{5 / 2}$ transition, and the samples with concentration 1 at. $\% \mathrm{Yb}^{3+}$ ions have no visible $\mathrm{Yb}^{3+}\left({ }^{2} \mathrm{~F}_{5 / 2}\right)$ transition.

The refractive indices were measured using variable angle spectroscopic ellipsometry (VASE, J.A.Woollam \& co.) working in rotating analyzer mode. The measurements were carried out in the spectral range from 300 to $1100 \mathrm{~nm}$. Fig. 6a shows the dependence of the refractive indices of the $\mathrm{Er}^{3+}$ doped PMMA (erbium (III)), and Fig. 6b shows the dependence of the refractive indices of the lat. $\% \mathrm{Er}^{3+}$ (erbium (III)) doped PMMA with $\mathrm{Yb}^{3+}$ co-doping (ytterbium (III)). It is obvious that increasing the content of $\mathrm{Er}^{3+}$ and $\mathrm{Er}^{3+}+\mathrm{Yb}^{3+}$ increases the refractive indices of the material.

The refractive index value is, also a matter of the polarizability of the ions present in the material [26]. Polarizability (or ion deformation) is understood as a function of the size of the ions - the larger the size, the larger the polarizability, and vice versa. The presence of larger cautions in the substance (in this case rather large $\mathrm{Er}^{3+}$ and/or $\mathrm{Yb}^{3+}$ the thin layer of polymer) usually raises the refractive index. The results are not surprising, but what is important is the exact refractive index value (of course depending on the wavelength) of the deposited material.

Semiconductor laser excitation (P4300 operating at $\lambda_{x}=980 \mathrm{~nm}$ with $E_{\mathrm{ex}}=500 \mathrm{~mW}$; room temperature) was used to detect sample luminescence in the range from 1450 to $1650 \mathrm{~nm}$. The photoluminescence spectra of the $\mathrm{Er}^{3+}$ doped samples (erbium (III)) are given in Fig. 7a, and the $\mathrm{Er}^{3+}$ doped samples $\left(\mathrm{ErF}_{3}\right)$ are given in Fig. $7 \mathrm{~b}$. In the case of erbium (III) only the samples with higher $\mathrm{Er}^{3+}$ concentra- 


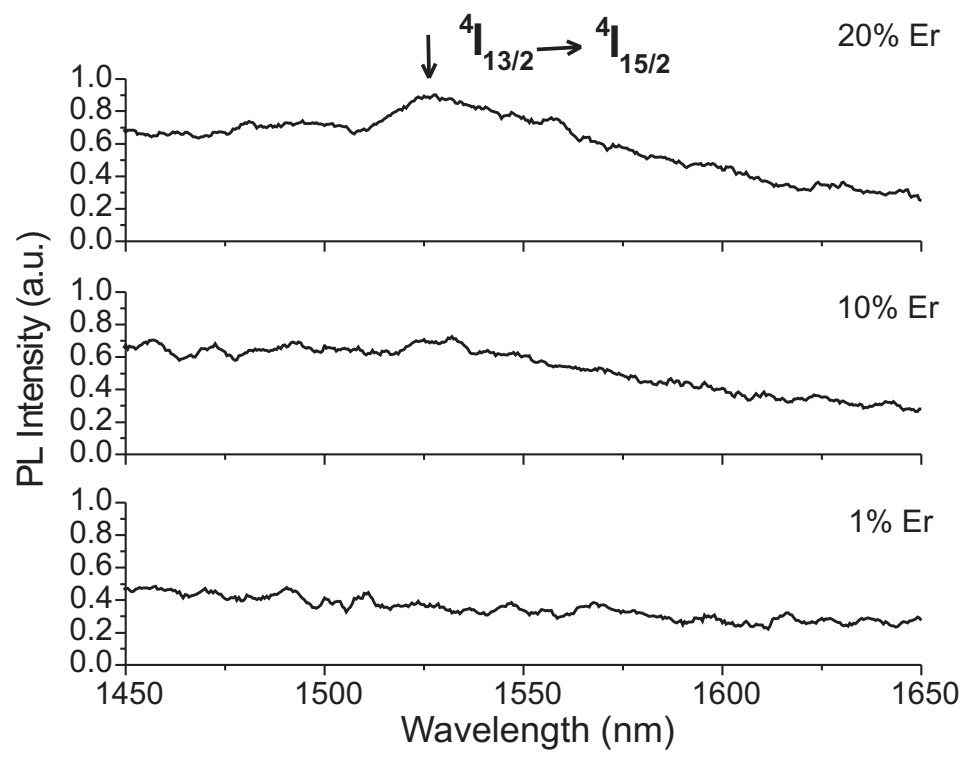

a)

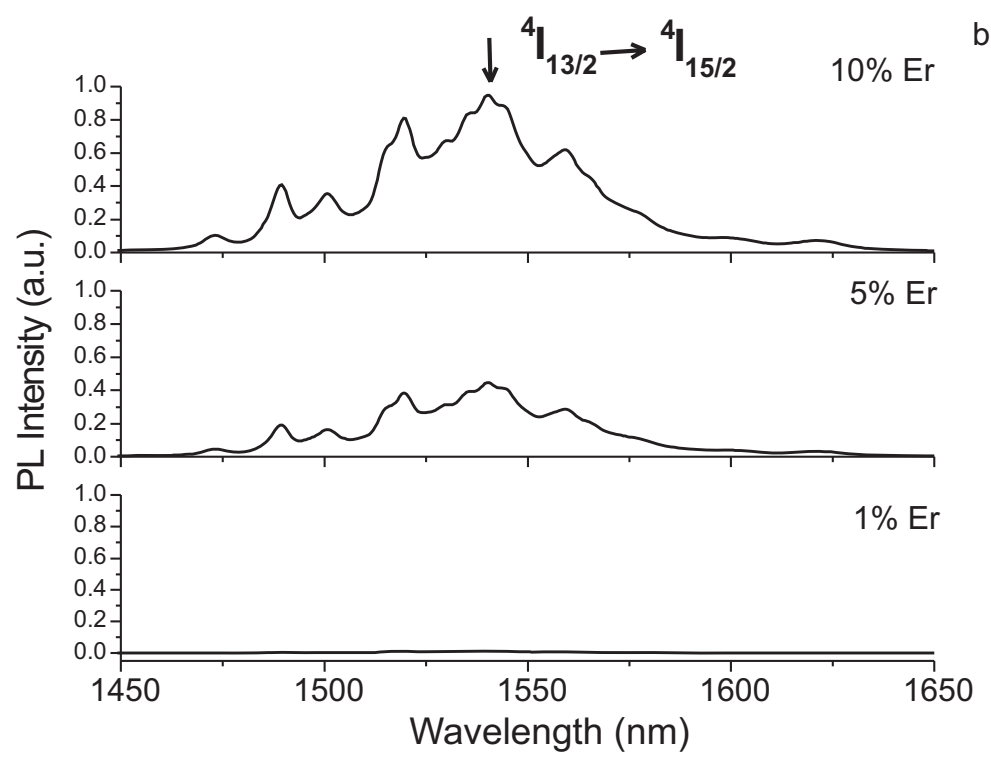

Fig. 7: Photoluminescence spectra of $\mathrm{Er}^{3+}$ doped PMMA layers a) (erbium(III)), b) $\operatorname{ErF}^{3+}\left(\lambda_{\mathrm{ex}}=980 \mathrm{~nm}\right.$ with $E_{\mathrm{ex}}=500 \mathrm{~mW}$; room temperature)

tions showed very weak photoluminescence bands at $1530 \mathrm{~nm}$ attributed to the erbium transition $4 \mathrm{I} 13 / 2 \rightarrow 4 \mathrm{I} 15 / 2$. In the case of $\mathrm{ErF}_{3}$, the emission intensity is higher than that of erbium (III) (See Fig. 7). The highest emission intensity was found in sample $\left(\mathrm{ErF}_{3}\right)$, which contained 10.0 at. \% erbium.

Fig. 8 shows the infrared emissions obtained for samples doped with 1.0 at.\% erbium and co-doped with ytterbium ions in amounts varying from 1.0 at. \% to 10.0 at. \% (Fig. 8a erbium(III), ytterbium(III) and Fig. $8 \mathrm{~b}_{\mathrm{ErF}}, \mathrm{YbF}_{3}$ ). The samples showed very weak emission at $1530 \mathrm{~nm}$. Therefore co-doping with ytterbium ions had only a weak effect on the photoluminescence spectra.

\section{Conclusion}

We have reported on the fabrication process and the properties of PMMA layers doped with $\mathrm{Er}^{3+}$ and $\mathrm{Er}^{3+}$ ions co-doped with $\mathrm{Yb}^{3+}$ ions.

- Polymer layers were fabricated by spin coating or by pouring the polymer into a bottomless mould placed on a glass substrate.

- We observed the FTIR absorption band at around $3349 \mathrm{~cm}^{-1}$ corresponding to the $\mathrm{O}-\mathrm{H}$ vibrations and three bands at $2994 \mathrm{~cm}^{-1}, 2953 \mathrm{~cm}^{-1}$ and $2843 \mathrm{~cm}^{-1}$ corresponding to the aliphatic C-H bands. 


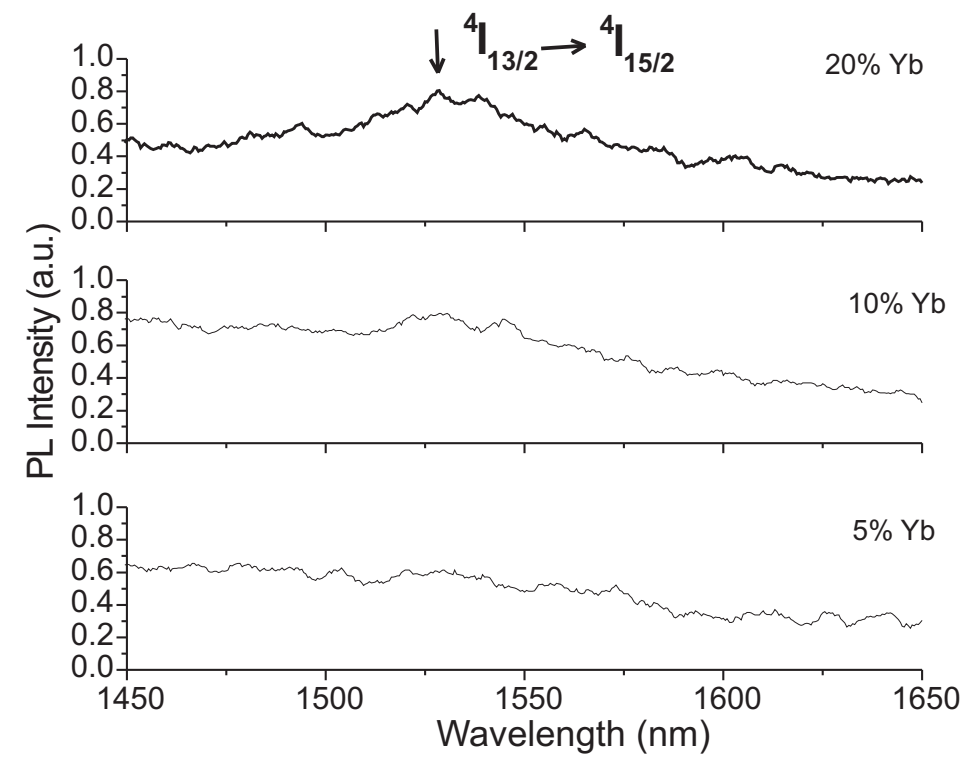

a)

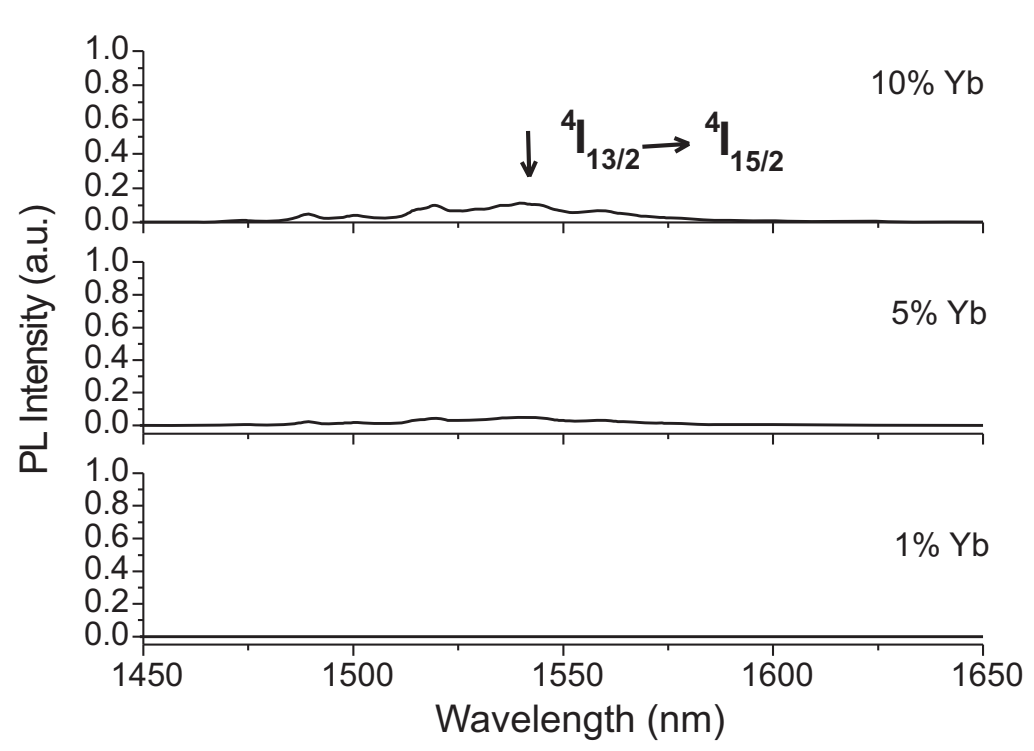

Fig. 8: Photoluminescence spectra of $\mathrm{Er}^{3+}+\mathrm{Yb}^{3+}$ doped PMMA layers (1.0 at. \% Er) a) (erbium(III), ytterbium(III)), b) $\mathrm{ErF}^{3+}, \mathrm{YbF}^{3+}$ ( $\lambda_{\mathrm{ex}}=980 \mathrm{~nm}$ with $E_{\mathrm{ex}}=500 \mathrm{~mW}$; room temperature)

- The content of $\mathrm{Er}^{3+}$ and $\mathrm{Er}^{3+}+\mathrm{Yb}^{3+}$ ions had a significant effect on the transmission spectra. We observed three bands corresponding to the $\mathrm{Er}^{3+}$ ions $\left({ }^{4} \mathrm{G}_{11 / 2}-377 \mathrm{~nm}\right.$, ${ }^{2} \mathrm{H}_{11 / 2}-519 \mathrm{~nm},{ }^{4} \mathrm{~F}_{9 / 2}-650 \mathrm{~nm}$ and one band corresponding to the $\mathrm{Yb}^{3+}$ ions $\left({ }^{2} \mathrm{~F}_{5 / 2}-977 \mathrm{~nm}\right)$. These bands we observed in the samples doped with a higher Er and $\mathrm{Yb}$ concentration, and they almost disappeared in the background in the case of samples with a low $\mathrm{Er}$ and $\mathrm{Yb}$ concentration.
- The refractive indices were investigated by spectroscopic ellipsometry and we found that increasing the content of the $\mathrm{Er}^{3+}$ and $\mathrm{Yb}^{3+}$ ions increases the refractive indices of the material.

- The $\mathrm{Er}^{3+}$ doped PMMA samples exhibited a typical emission at $1530 \mathrm{~nm}$, due to the $\mathrm{Er}^{3+}$ intra-4f ${ }^{4} \mathrm{I}_{13 / 2} \rightarrow{ }^{4} \mathrm{I}_{5 / 2}$ only at samples with higher content of $\mathrm{Er}^{3+}$ ions. The highest emission intensity was found in sample $\left(\mathrm{ErF}_{3}\right)$ containing 10.0 at. \% erbium. It was also found that the addi- 
tion of ytterbium did not substantially affect the $1530 \mathrm{~nm}$ luminescence.

\section{Acknowledgments}

Our research has been supported by the Grant Agency of the Czech Republic under grant number 102/06/0424 and research program MSM6840770014 of the Czech Technical University in Prague.

\section{References}

[1] Steckl, A. J., Zavada, J. M.: Optoelectronic Properties and Applications of Rare-Earth-Doped GaN. MRS Bulletin, Vol. 24 (1999), Issue 9, p. 33-38.

[2] Steckl, A. J., Heikenfeld, J., Lee, D. S., Garter, M.: Multiple Color Capability from Rare Earth-Doped Gallium Nitride. Materials Science and Engineering B-Solid State Materials for Advanced Technology, Vol. 81 (2001), Issue 1-3, p. 97-101.

[3] Kenyon, A. J.: Recent Developments in Rare-Earth Doped Materials for Optoelectronics. Progress in Quantum Electronics, Vol. 26 (2002), No. 4-5, p. 225-284.

[4] van den Hoven, G. N., Snoeks, E., Polman, A., Vanuffelen, J. W. M., Oei, Y. S., Smit, M. K.: Photoluminesce Characterization of Er-Implanted $\mathrm{Al}_{2} \mathrm{O}_{3}$ Films. Applied Physics Letters, Vol. 62 (1993), No. 24, p. 3065-3067.

[5] Kik, P. G., Polman, A.: Erbium Doped Optical-Waveguide Amplifiers on Silicon. MRS Bulletin, Vol. 23 (1998), Issue 4, p. 48-54.

[6] Chiasera, A., Tosello, C., Moser, E., Montagna, M., Belli, R., Goncalves, R. R., Righini, G. C., Pelli, S., Chiappini, A., Zampedri, L., Ferrari, M.: $\mathrm{Er}^{3+} / \mathrm{Yb}^{3+}-\mathrm{Ac}-$ tivated SilicaTitania Planar Waveguides for EDPWAs Fabricated by RF-Sputtering. Journal of Non-Crystalline Solids, Vol. 322 (2003), Issue 1-3, p. 289-294.

[7] Steckl, A. J., Heikenfeld, J. C., Lee, D. S., Garter, M. J., Baker, C. C., Wang, Y. Q., Jones, R.: Rare-Earth-Doped GaN: Growth, Properties, and Fabrication of Electroluminescent Devices. IEEE Journal of Selected Topics in Quantum Electronics, Vol. 8 (2002), No. 4, p. 749-766.

[8] Wang, J. S., Vogel, E. M., Snitzer, E., Jackel, J. L., da Silva, V. L., Silberberg, Y.: $1.3 \mu \mathrm{m}$ Emission of Neodymium and Praseodymium in Tellurite-Based Glasses. Journal of Non-Crystalline Solids, Vol. 178 (1994), p. 109-113.

[9] Man, S. Q., Pun, E. Y. B., Chung, P. S.: Tellurite Glasses for $1.3 \mu \mathrm{m}$ Optical Amplifiers. Optics Communications, Vol. 168 (1999), Issues 5-6, p. 369-373.

[10] Samson, B. N., Neto, J. A. M., Laming, R. I., Hewak, D. W.: Dysprosium Doped Ga:La:S Glass for an Efficient Optical Fiber Amplifier Operating at $1.3 \mu \mathrm{m}$. Electronics Letters, Vol. 30 (1994), Issue 19, p. 1617-1619.

[11] Machewirth, D. P., Wei, K., Krasteva, V., Datta, R., Snitzer, E., Sigel, G. H.: Optical Characterization of $\operatorname{Pr}^{3+}$ and $\mathrm{Dy}^{3+}$ Doped Chalcogenide Glasses. Journal of Non-Crystalline Solids, Vol. 213 (1997), p. 295-303.

[12] Yan, Y. C., Faber, A. J., deWaal, H., Kik, P. G., Polman, A.: Erbium-Doped Phosphate Glass Waveguide on Silicon with $4.1 \mathrm{~dB} / \mathrm{cm}$ Gain at $1.535 \mu \mathrm{m}$. Applied Physics Letters, Vol. 71 (1997), Issue 20, p. 2922-2924.

[13] Shmulovich, J., Wong, A., Wong, Y. H., Becker, P. C., Bruce, A. J., Adar, R.: $\mathrm{Er}^{3+}$ Glass Wave-guide Amplifier at $1.5 \mu \mathrm{m}$ on Silicon. Electronics Letters, Vol. 28 (1992), Issue 13, p. 1181-1182.

[14] Kasamatsu, T., Yano, Y., Sekita, H.: $1.50 \mu \mathrm{m}$-Band Gain-Shifted Thulium-Doped Fiber Amplifier with 1.05 and $1.56 \mu \mathrm{m}$ Dual-Wavelength Pumping. Optics Letters, Vol. 24 (1999), Issue 23, p. 1684-1686.

[15] Chryssou, C. E., Di Pasquale, F., Pitt, C. W.: Improved Gain Performance in $\mathrm{Yb}^{3+}$-Sensitized $\mathrm{Er}^{3+}$-Doped Alumina $\left(\mathrm{Al}_{2} \mathrm{O}_{3}\right)$ Channel Optical Waveguide Amplifiers. Journal of Lightwave Technology, Vol. 19 (2001), Issue 3, p. 345-349.

[16] Strohhofer, C., Polman, A.: Relationship between Gain and $\mathrm{Yb}^{3+}$ Concentration in $\mathrm{Er}^{3+} \mathrm{Yb}^{3+}$ Doped Waveguide Amplifier. Journal of Applied Physics Letters, Vol. 90 (2001) No. 9, p. 4314-4320.

[17] Bourdet, G. L., Muller, R. A.: Tm,Ho:YLF Microchip Laser under Ti:Sapphire and Diode Dumping. Applied Physics B-Lasers and Optics, Vol. 70 (2000), Issue 3, p. 345-349.

[18] Sani, E., Toncelli, A., Tonelli, M., Coluccelli, N., Galzerano, G., Laporta, P.: Comparative Analysis of Tm-Ho:KYF 4 Laser Crystals. Applied Physics B - Lasers and Optics, Vol. 81 (2005), Issue 6, p. 847-851.

[19] Li, J., Wang, J. Y., Tan, H., Cheng, X. F., Song, F., Zhang, H. J., Zhao, S. R.: Growth and Optical Properties of $\mathrm{Ho}, \mathrm{Yb}: \mathrm{YAl}_{3}\left(\mathrm{BO}_{3}\right)_{4}$. Crystal Journal of Crystal Growth, Vol. 256 (2003), Issue 3-4, p. 324-327.

[20] Digonnet, J. F. M.: Rare-Earth-Doped Fiber Lasers and Amplifiers. Stanford, California: Marcel Dekker Inc. 1993.

[21] Eldada, L., Shacklette, L. W.: Advances in Polymer Integrated Optics. IEEE Journal of Selected Topics in Quantum Electronics, Vol. 6 (2000), No.1, p. 54-68.

[22] Wong, W. H., Liu, K. K., Chan, K. S., Pun, E. Y. B.: Polymer Devices for Photonics Applications. Journal of Crystal Growth, Vol. 288 (2006), Issue 1, p. 100-104.

[23] Liang, H., Zheng, Z. Q., Zhang, Q. J., Ming, H., Chen, B., Xu, J., Zhao, H.: Radiative Properties of Eu(DBM)(3) Phen-Doped Poly(methyl methacrylate). Journal of Materials Research, Vol. 18 (2003), Issue: 8, p. 1895-1899.

[24] Sosa, R., Flores, M., Rodriguez, R., Munoz, A.: Optical Properties and Judd-Ofelt Intensity Parameters of $\mathrm{Eu}^{3+}$ in PMMA: PAAc Copolymer Samples. Revista Mexicana de Fisica, Vol. 46 (2003), Issue 6, p. 519-524.

Ing. Václav Prajzler, Ph.D.

e-mail:xprajzlv@feld.cvut.cz

Ing. Vitězslav Jeřábek, CSc.

e-mail: Jerabek@fel.cvut.cz

Department of Microelectronics

Faculty of Electrical Engineering

Czech Technical University in Prague

Technická 2

16627 Prague, Czech Republic 
Mgr. Oleksei Lyutakov

Doc. Ing. Ivan Hüttel, DrSc.

e-mail: Ivan.Huttel@vscht.cz

RNDr. Jarmila Špirková, CSc.

e-mail: Jarmila.Spirkova@vscht.cz

Ing. Vladimír Machovič, CSc.

Institute of Chemical Technology

Technická 5, 16627 Prague, Czech Republic

Ing. Jiří Oswald, CSc.

e-mail: Oswald@fzu.cz

RNDr. Dagmar Chvostová

e-mail: chvostov@fzu.cz

Institute of Physics

Academy of Sciences Czech Republic, v. v. i.

Cukrovarnická 10/112

16253 Prague 6, Czech Republic

RNDr. Jiří Zavadil, CSc.

e-mail: Zavadil@ufe.cz

Institute of Photonics and Electronics

Academy of Sciences Czech Republic, v. v. i.

Chaberská 57

18251 Prague, Czech Republic 